\title{
KARAKTERISTIK ASAM AMINO PADA GELATIN KULIT KAKI TERNAK DAN KAJIAN POTENSI ANTIBAKTERINYA
}

\author{
MIWADA, I N. S. DAN I K. SUKADA \\ Fakultas Peternakan, Universitas Udayana \\ Jl. PB. Sudirman Denpasar \\ e-mail: nymsumerta@yahoo.co.id
}

\begin{abstract}
ABSTRAK
Tujuan penelitian adalah mengidentifikasi karakter asam amino pada kulit kaki ternak jenis ayam broiler (G1), sapi (G2) dan kambing (G3) yang telah dihidrolisis menjadi gelatin. Hasil penelitian menunjukkan bahwa baik pada gelatin (G1); (G2) dan (G3) didominasi oleh asam amino esensial jenis histidin dan arginin. Jenis asam amino non esensial didominasi oleh glutamat dan serin. Analisis morfologi permukaan gelatin dengan pendekatan SEM bahwa permukaan struktur molekul gelatin dari ekstraksi kulit kaki ayam lebih halus dan rata. Sementara pada hasil ekstraksi kulit kaki sapi dan kambing masih banyak terdeteksi bundelan ikatan protein kolagen yang tidak terekstrak sempurna. Potensi gelatin dari aneka kulit kaki ternak ini dilakukan pengujian terhadap potensi anti bakterinya. Hasil penelitian menunjukkan bahwa gelatin (G1), (G2) dan (G3) tidak memiliki kemampuan sebagai antibakteri patogen baik terhadap jenis Salmonella typhii, Escherichia coli, dan staphylococcus aureus. Kesimpulan penelitian bahwa profil asam amino gelatin dominan yang terdeteksi yakni asam amino esensial jenis histidin dan arginin serta asam amino non esensial jenis glutamat dan serin. Analisis morfologi gelatin dengan pendekatan SEM adalah terjadi permukaan yang halus pada G1. Sedangkan gelatin dari G2 terlihat belum terekstrak sempurna dan bahkan G3 lebih padat. Hasil uji gelatin terhadap kemampuan penghambatan bakteri patogen menunjukkan hasil yang negative.
\end{abstract}

Kata kunci: kulit kaki ternak, gelatin, asam amino, SEM

\section{THE STUDY OF AMINO ACID CHARACTERISTIC ON FOOT SKIN GELATIN LIVESTOCK AND ANTIBACTERIAL}

\begin{abstract}
The purpose of this study is to identify amino acids in the skin character leg of chicken broiler (G1), cattle (G2) and goats (G33) which has been hydrolyzed to gelatin. The results showed that both gelatin G1; G2 and G3 are dominated by a kind of essential amino acid histidine and arginine. Analysis of the morphology of gelatin surface with SEM approach surface structure of the gelatin molecule extraction chicken leg skin more smooth and flat. However, the foot of the extracted skin of cattle and goats still bundles detectable binding protein extracted collagen was not perfect. Potential skin gelatin of various livestock leg was conducted testing potential anti-bacterial. The results showed that the gelatin $\left(\mathrm{G}_{1}\right),(\mathrm{G} 2)$ and $\left(\mathrm{G}_{3}\right)$ did not possess the antibacterial ability of pathogens either to Salmonella typhii, Escherichia coli and Staphylococcus aureus. It can be concluded that the dominant gelatin amino acid profile detected essential amino acid histidin and arginin and nonessential amino acid glutamic acid and serine types. Gelatin morphology analysis results with SEM approach going on G1 smooth surface, while the gelatin of G2 looks not extracted perfectly and even $\mathrm{G}_{3}$ is denser. Gelatin test results on the ability of pathogenic bacteria inhibition showed negative results.
\end{abstract}

Keywords: skin foot cattle, gelatin, amino acid, SEM

\section{PENDAHULUAN}

Kulit kaki ternak adalah by product dari pemotongan ternak dan selama ini potensinya belum maksimal dimanfaatkan. Kulit kaki ternak, seperti kulit kaki ayam broiler, kulit kaki kambing dan kulit kaki sapi secara struktur histologi adalah sama yakni tersusun dari epidermis dan korium. Korium adalah komponen utama pada kulit khususnya pada kulit kaki ternak dan didominasi oleh protein kolagen (Brown et al., 1997), 
meskipun dalam persentaseyang berbeda-beda(Miwada dan Simpen, 2014). Djojowidagdo (1988) menyebutkan bahwa semakin tua umur ternak, komposisi kulit khususnya protein kolagen semakin tinggi, kadar lemak semakin tinggi, namun persentase kadar abunya semakin rendah. Soeparno (1998) mengatakan bahwa jumlah dan kekuatan fisik kolagen dapat meningkat sejalan dengan meningkatnya umur hewan. Swatland (1984) menjelaskan bahwa serabut kolagen mempunyai diameter 1-12 $\mu \mathrm{m}$, sedangkan ikatan-ikatan paralel fibrilal penyusun serabut kolagen berdiameter 20$100 \mathrm{~nm}$. Lebih lanjut disebutkan bahwa kecepatan pertumbuhan berkas serabut kolagen semakin menurun sampai pada umur tertentu sampai akhirnya mencapai konstan. Sarkar (1995) menyebutkan bahwa kolagen pada kulit hewan kecil berkisar antara 30-33\% (berat kering, bk), pada kulit anak sapi ( $84 \%$ bk), sapi dewasa $(87,2 \%$ bk) dan sapi jantan (95,1\% bk).

Selama ini, belum ada kajian tentang potensi protein pada kulit kaki ternak jenis kulit pada kaki ayam broiler, sapi dan kambing. Khususnya tentang profil asam amino penyusun protein pada kulit kaki ternak yang telah terhidrolisis menjadi produk gelatin. Pentingnya kajian ini, mengingat potensi hidrolisis protein kolagen menjadi gelatin merupakan produk potensial yang sangat ditentukan oleh asam amino penyusunnya. Miwada et al. (2015) menyebutkan bahwa pemanfaatan kulit kaki ternak sebagai gelatin dan diimplemantasikan sebagai edible merupakan upaya peningkatan nilai tambah dari by product ini. Hal ini didukung oleh Apriantono (2003), menyebutkan bahwa gelatin dapat dibuat dari bahan yang kaya akan kolagen seperti kulit. Lebih lanjut disebutkan tentang manfaat gelatin sangat fleksibel, yaitu bisa berfungsi sebagai bahan pengisi (dalam pembuatan kapsul obat), pengemulsi, pengikat, pengendap, pemerkaya gizi, dan dapat membentuk lapisan tipis elastis serta dapat membentuk lapisan film yang transparan, kuat, dan daya cernanya tinggi. Tujuan penelitian ini adalah mengidentifikasi karakater asam amino pada kulit kaki ternak jenis ayam broiler, sapi dan kambing yang telah dihidrolisis menjadi gelatin. Disamping itu, juga untuk mengamati secara morfologis produk gelatin yang dihasilkan dengan pendekatan SEM (Scaning Electron Microscope) dan mengidentifikasi potensi gelatin berbasis kulit kaki ternak terhadap kemampuannya sebagai antibakteri pada jenis Salmonella typhii, Escherichia coli, dan staphylococcus aureus.

\section{BAHAN DAN METODE}

\section{Bahan}

Materi utama penelitian yakni kulit kaki ternak jenis kulit kaki ayam (G1), kulit kaki kambing (G3), dan kulit kaki sapi (G2) masing-masing $1 \mathrm{~kg}$. Bahan kimia meliputi asam asetat (1,5\%), etanol, buffer $\mathrm{pH} 4,00$, buffer $\mathrm{pH}$ 7,00, buffer $\mathrm{pH}$ 9,00, dan aquades. Bahan uji mikrobiologi meliputi nutrien agar, PDA, Bahan pendukung lainnya seperti air bebas ion (deionized water), kertas saring biasa, dan kertas saring Whatman 42.

\section{Metode}

Tahap pelaksanaan penelitian, dimulai dengan pembuatan larutan asam asetat dengan konsentrasi 1,5\%. Selanjutnya , kulit kaki ayam, kulit kaki kambing dan kulit kaki sapi yang telah disiapkan dengan metode pengulitan konvensional dan persiapan hidrolisis protein kulit kaki ternak dengan metode Miwada dan Simpen (2007 dan 2013) termodifikasi yang meliputi tahap curing dengan asam asetat konsentrasi $1,5 \%$ dengan perbandingan (1:8). Curing dilakukan selama 3 hari, dilanjutkan dengan minimalisasi kandungan lemak dengan menggunakan larutan etanol 65\% (rasio gelatin : etanol yakni $1: 2$ ) dengan perendaman dalam 1 jam. Hasil minimalisasi lemak, dilanjutkan dengan ekstraksi dengan penambahan aquades (rasio $1: 1$ ) dan dilakukan pemanasan dalam water bath dengan suhu $61^{\circ} \mathrm{C}-65^{\circ} \mathrm{C}$ selama 1 jam, dilanjutkan dengan pencucian, penyaringan, penguapan larutan pengekstrak, dan pengentalan produk gelatin yang diperoleh. Uji karakteristik gelatin dari bahan baku kulit yang berbeda diuji melalui metode HPLC, pengamatan morfologi gelatin (dengan pendekatan SEM) dan uji daya hambat bakteri terhadap jenis-jenis Salmonella typhii, Escherichia coli, dan Staphylococcus aureus.

\section{HASIL DAN PEMBAHASAN}

Kegiatan penelitian ini diawali dengan penentuan profil asam amino pada gelatin dari aneka kulit kaki ternak yng telah diproduksi. Proses produksi gelatin aneka kulit kaki ternak ini dilakukan dengan metode Miwada dan Simpen (2007 dan 2013) yang sedikit dimodifikasi. Produk gelatin kering yang dihasilkan diuji kandungan asam amino masing-masing dengan metode HPLC. Deskripsi dari asam amino pada masing-masing gelatin kulit kaki ternak disajikan pada gambar berikut.

Secara kuantitatif, gambaran komponen asam amino pada gelatin dari aneka kulit kaki ternak dapat disajikan pada Tabel 1.

Hasil penelitian ini menunjukkan bahwa baik pada gelatin G1; G2 dan G3 didominasi oleh asam amino esensial jenis histidin dan arginin. Sementara jenis asam amino non esensial didominasi oleh glutamat dan serin. Pearson dan Dutson (1992) menyebutkan bahwa pada saat proses curing telah terjadi perubahan akibat terdenaturasinya protein kolagen kulit dan beberapa 


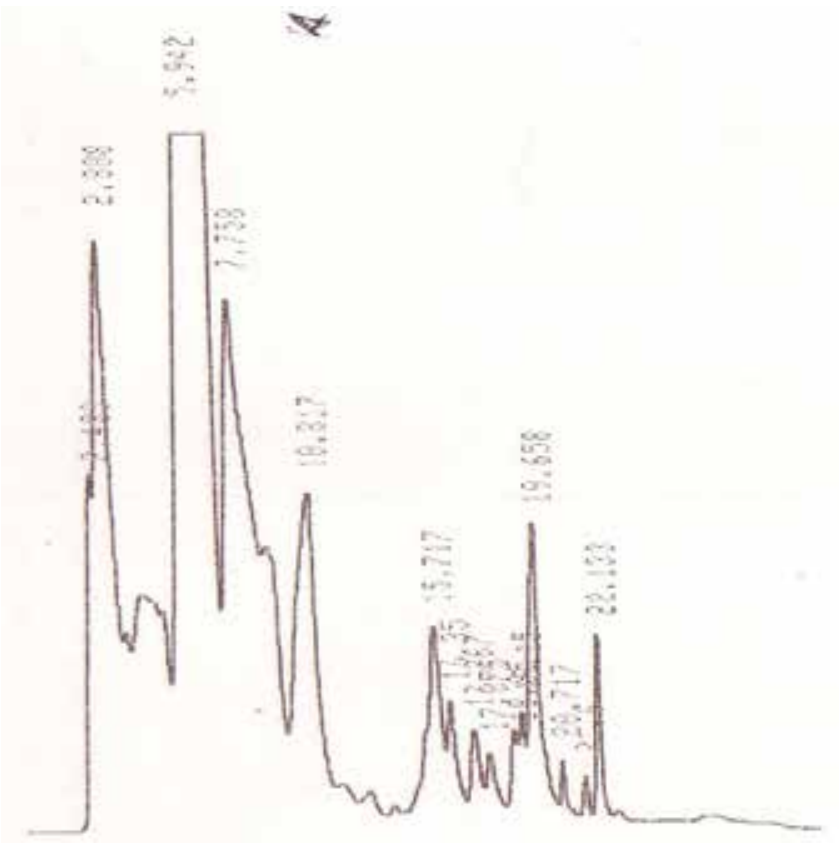

Gambar 1. Deskripsi profil asam amino gelatin kulit kaki ayam.

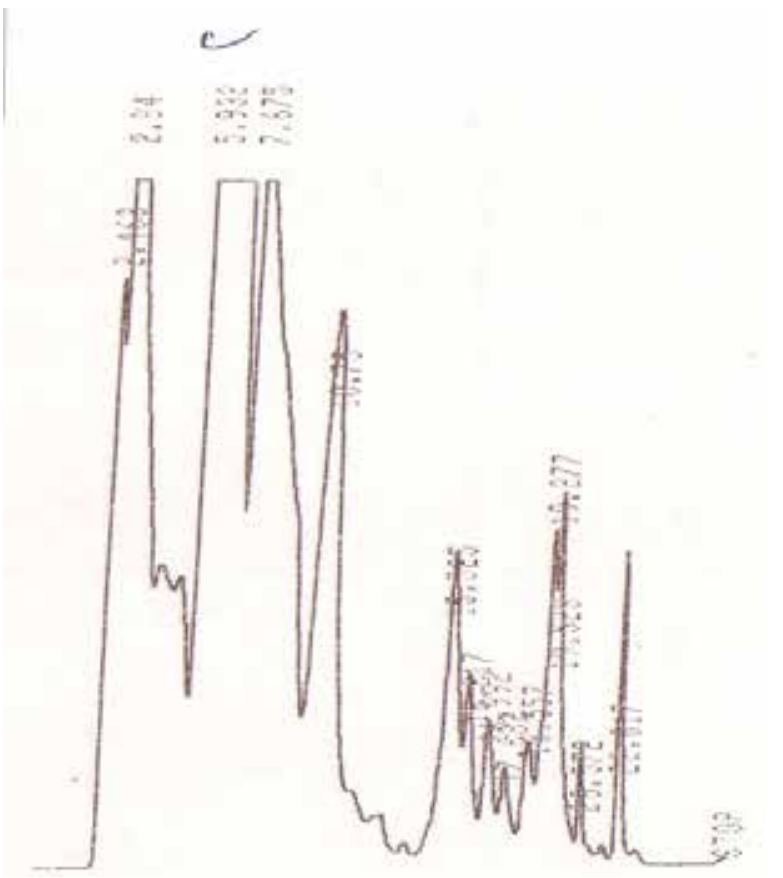

Gambar 3. Deskripsi profil asam amino gelatin kulit kaki kambing.

asam amino tertentu berubah secara kimia. Namun demikian, hal menarik yang ditemukan pada penelitian ini (Tabel 1) bahwa asam amino esensial dan non esensial terdeteksi sama tinggi baik pada gelatin G1; G2 dan G3 jika dibandingkan menurut referensi Cshrieber dan Gareis (2007).

Analisis morfologi permukaan gelatin hasil ekstraksi dengan asam asetat (konsentrasi 1,5\%) selama 3 hari dikaji melalui pendekatan SEM (Scanning Electron

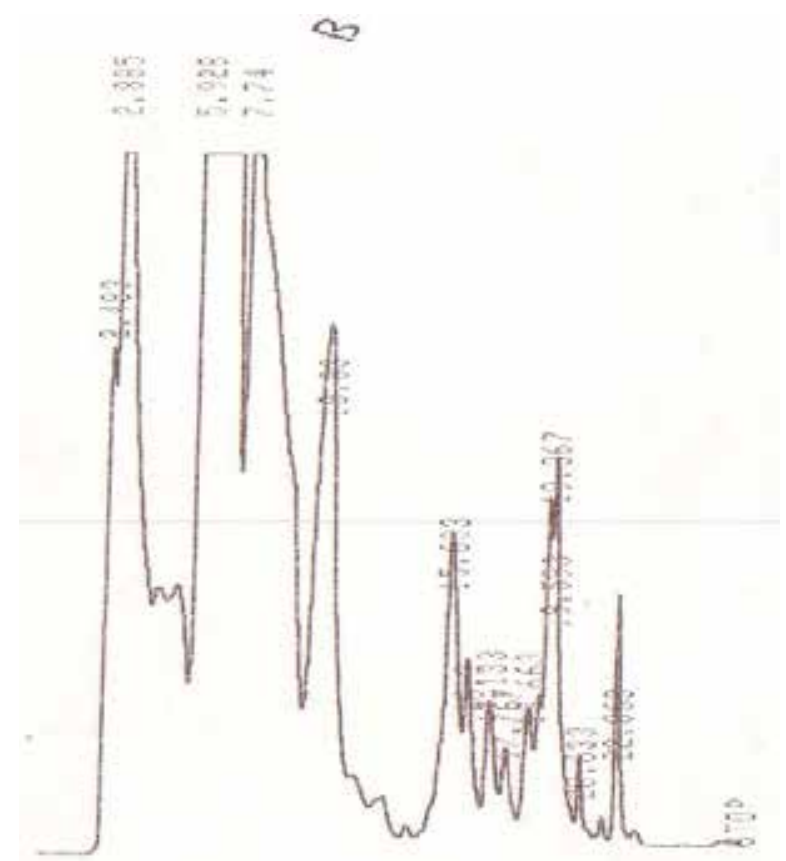

Gambar 2. Deskripsi Profil asam amino gelatin kulit kaki sapi.

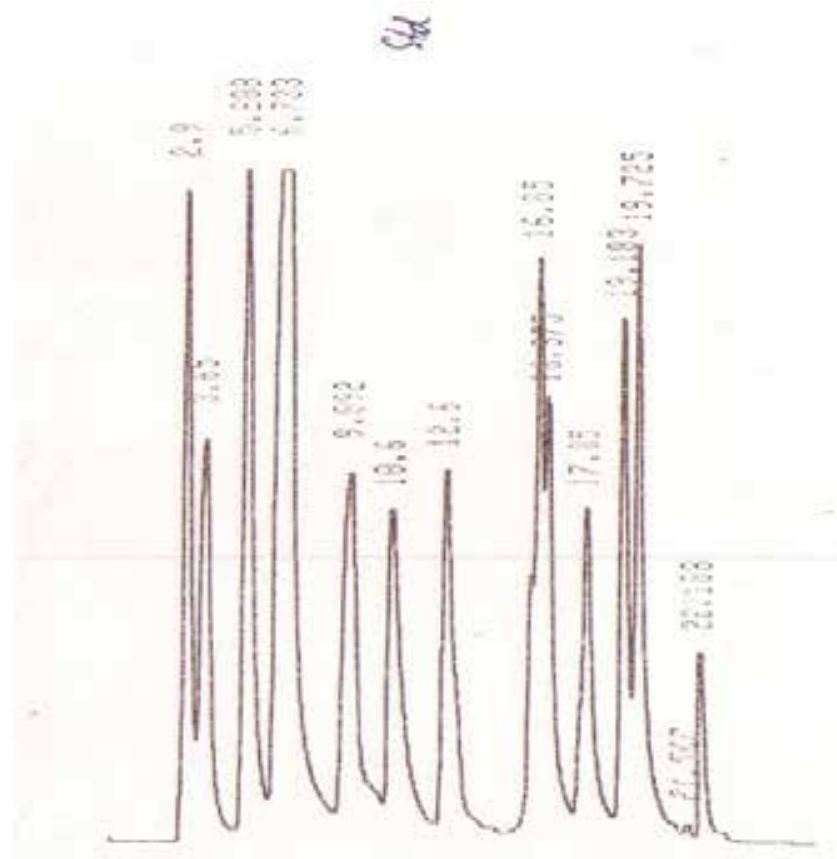

Gambar 4. Deskripsi standar profil asam amino.

Microscope). Hasil analisis secara lengkap dapat dilihat pada Gambar 1. Berdasarkan hasil uji SEM terlihat bahwa permukaan struktur molekul gelatin dari ekstraksi kulit kaki ayam lebih halus dan rata. Sementara pada hasil ekstraksi kulit kaki sapi masih banyak terdeteksi bundelan ikatan protein kolagen yang tidak terekstrak sempurna. Ekstraksi protein kolagen kulit kaki kambing pada gambar 1, cenderung lebih padat lagi, dan bahan curing asam asetat konsentrasi 
Tabel 1. Karakteristik asam amino gelatin dari aneka kulit kaki ternak

\begin{tabular}{lrrrr}
\hline \multirow{2}{*}{ Asam amino } & \multicolumn{3}{c}{ Konsentrasi (\%) } & \\
\cline { 2 - 4 } & $\begin{array}{c}\text { Gelatin kulit } \\
\text { kaki ayam }\end{array}$ & $\begin{array}{c}\text { Gelatin kulit } \\
\text { kaki sapi }\end{array}$ & $\begin{array}{r}\text { Gelatin kulit } \\
\text { kaki kambing }\end{array}$ & \\
\hline Aspartic Acid & 3,018 & 3,038 & 3,668 & 2,900 \\
Glutamic & 10,169 & 10,796 & 11,782 & 4,800 \\
Serin & 9,470 & 9,604 & 9,903 & 3,500 \\
Histidin & 11,185 & 11,553 & 11,775 & 0,400 \\
Glycin & 2,754 & 3,019 & 3,205 & 33,000 \\
Threonin & 6,353 & 6,777 & 6,947 & 1,800 \\
Arginin & 6,094 & 6,508 & 6,815 & 4,900 \\
Alanin & 1,387 & 1,359 & 1,450 & 11,200 \\
Tyrosin & 1,486 & 1,682 & 1,801 & 0,260 \\
Methionin & 1,205 & 1,471 & 1,545 & 0,360 \\
Valin & 1,553 & 1,498 & 1,492 & 2,600 \\
Phenylalanin & 1,111 & 1,111 & 1,165 & 1,400 \\
Isoleusin & 3,114 & 3,156 & 2,871 & 1,00 \\
Leucin & 12,554 & 11,472 & 12,351 & - \\
Lysin & 7,516 & 7,336 & 7,117 & 2,700 \\
\hline
\end{tabular}

1,5\% selama 3 hari belum mampu memaksimalkan jumlah gelatin dari kulit kaki kambing untuk terekstrak sempurna. Hasil analisis permukaan gelatin pada kulit kaki ternak ini dengan pendekatan SEM dikuatkan lagi dengan temuan yang dilaporkan oleh Miwada et al. (2015) bahwa ekstraksi kulit kaki ternak dengan metode curing asam asetat $(1,5 \%)$ selama 3 hari menghasilkan volume gelatin yang terekstrak dari protein kolagen tertinggi pada kulit kaki ayam diikuti kulit kaki sapi dan kulit kaki kambing.

Potensi gelatin dari aneka kulit kaki ternak ini dilakukan pengujian terhadap potensi antibakterinya. Hasil penelitian menunjukkan bahwa gelatin dari kulit kaki ayam (G1), kulit kaki sapi (G2) dan kulit kaki kambing (G3) tidak memiliki kemampuan sebagai antibakteri patogen baik terhadap jenis Salmonella typhii, Escherichia coli, dan Staphylococcus aureus. Hal itu, dibuktikan oleh Miwada dan Simpen (2014) bahwa kandungan bakteri dan total coliform bakso masih tinggi selama penyimpanan bakso yang mendapat perlakuan pengemasan alami (edible coating) dari jenis gelatin ini, dan sebagai indikasi tidak adanya potensi untuk menghambat pertumbuhan bakteri.

\section{SIMPULAN}

Hasil penelitian dapat disimpulkan bahwa karakteristik asam amino dominan yang terdeteksi baik pada gelatin dari kulit kaki ayam (G1), kulit kaki sapi (G2) dan kulit kaki kambing (G3) yakni asam amino esensial jenis histidin dan arginin serta asam amino non esensial jenis glutamat dan serin. Hasil analisis morfologigelatin dengan pendekatan SEM adalah terjadi permukaan yang haluspada G1. Sedangkan gelatin dari G2 terlihat belum terekstrak sempurna dan bahkan G3 lebih padat lagi. Hasil uji gelatin terhadap kemampuan penghambatan bakteri patogen menunjukkan hasil yang negatif (tidak ditemukan zona hambat).

\section{UCAPAN TERIMA KASIH}

Pada kesempatan ini tim peneliti mengucapkan banyak terima kasih kepada Dirjen Dikti dalam hal ini melalui Universitas Udayana dengan bantuan dana hibah Bersaing sehingga kegiatan penelitian ini dapat berjalan dengan baik.

\section{DAFTAR PUSTAKA}

Apriyantono, H. A. 2003. Makalah Halal: Kaitan Antara Syar'i, Teknologi, dan Sertifikasi. www.indohalal.com/ doc-halal2.html.

Brown, E. M., G. King dan J.M. Chen. 1997. Model of the helical portion of a type i collagen microfibril. Jalca.92.1-7.

Djojowidagdo, S. 1988. Kulit Kerbau Lumpur Jantan, Sifatsifat, dan Karakteristiknya Sebagai Bahan Wayang Kulit Purwa. Disertasi. Universitas Gadjah Mada, Yogyakarta.

Miwada, I N.S. dan I N. Simpen. 2007. Optimalisasi potensi ceker ayam (shank) hasil limbah RPA melalui metode ekstraksi termodifikasi untuk menghasilkan gelatin. Majalah Ilmiah Peternakan 10(1): 5-8.

Miwada, I N. S. dan Simpen, I N. 2013. Kajian waktu curing asam asetat dan rasio kombinasi kloroform-etanol untuk ekstraksi protein kulit ceker. Majalah Ilmiah
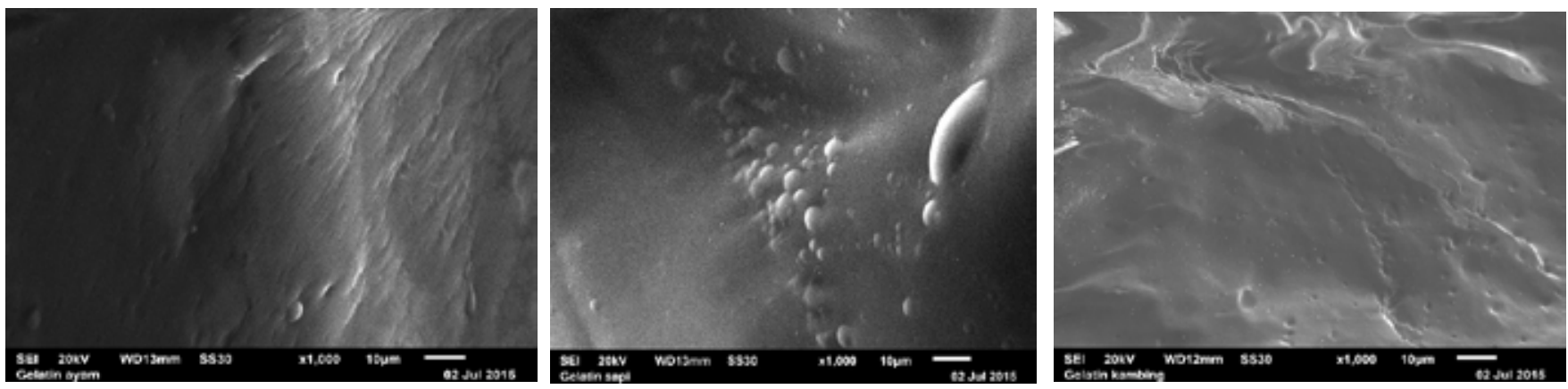

Gambar 1. Penampang gelatin dari kulit kaki ayam broiler, kulit kaki sapi dan kulit kaki kambing dengan perbesaran 1000x 
Peternakan 16(1):28-31.

Miwada, I N. S. dan I N. Simpen. 2014. Produksi dan Formulasi Edible Coating Berbasis Gelatin dari Kulit Kaki Ternak dan Potensinya dalam Mempertahankan Kualitas Bakso. Laporan Penelitian Hibah Bersaing. Universitas Udayana.

Miwada, I N. S., I N. Simpen, M. Hartawan, A.W. Puger dan N. L. P. Sriyani. 2015. Karakteristik gelatin dari kulit kaki ternak dan potensinya sebagai edible film. Majalah Ilmiah Peternakan. 18(3) : 109-113.

Pearson, A. M. and Dutson T. R. 1992. Inedible meat by product advances in meat. Research. Vol. 8. London dan New York.

Sarkar, K. T. 1995. Theory and Practice of Leather Manufacture. Publ. The Author 4. Second Avenue Mahatma Gandhi Road. Madras.

Schrieber, R. and H. Gareis. 2007. Gelatine Hanbook Theory and Industrial Practice. WILEY-VCH Verlag Gmbh \& Co. KGaA, Weinheim.

Soeparno. 1998. Ilmu dan Teknologi Daging. Gadjah Mada University Press. Yogyakarta.

Swatland, HJ. 1984. Structure and Development of Meat Animals. 56-63. Prentice Hall. Inc. Englewood Cliffs. New Jersey. 